\section{Investigation of Halohydrins Degradation by Whole Cells and Cell-free Extract of Pseudomonas putida DSM 437: A Kinetic Approach}

\author{
A. Konti, D. Mamma, and D. Kekos* \\ Biotechnology Laboratory, School of Chemical Engineering, \\ National Technical University of Athens, 9 Iroon Polytechniou Str, \\ Zografou Campus, 15773, Athens, Greece
}

doi: 10.15255/CABEQ.2016.924

Original scientific paper

Received: June 28, 2016

Accepted: August 31, 2017

The biodegradation of two halohydrins (1,3-dichloro-2-propanol and 3-chloro-1,2propanediol) by $P$. putida DSM 437 was investigated. Intact cells of previously acclimatized $P$. putida DSM 437 as well as cell-free extracts were used in order to study the degradation kinetics. When whole cells were used, a maximum biodegradation rate of 3-CPD $\left(v_{m}=1.28 \cdot 10^{-5} \mathrm{mmol} \mathrm{mg}^{-1} \mathrm{DCW} \mathrm{h}^{-1}\right)$ was determined, which was more than 4 times higher than that of 1,3-DCP. However, the affinity towards both halohydrins $\left(K_{\mathrm{m}}\right)$ was practically the same. When using cell-free extract, the apparent $v_{\max }$ and $K_{\mathrm{m}}$ values for 1,3-DCP were estimated at $9.61 \cdot 10^{-6} \mathrm{mmol} \mathrm{mg}^{-1}$ protein $\mathrm{h}^{-1}$ and $8.00 \mathrm{mM}$, respectively, while for 3-CPD the corresponding values were $2.42 \cdot 10^{-5} \mathrm{mmol} \mathrm{mg}^{-1}$ protein $^{-1}$ and 9.07 $\mathrm{mM}$.

GC-MS analysis of cell-free extracts samples spiked with 1,3-DCP revealed the presence of 3-CPD and glycerol, intermediates of 1,3-DCP degradation pathway. 3-CPD degradation was strongly inhibited by the presence of epichlorohydrin and to a lesser extent by glycidol, intermediates of dehalogenation pathway.

Key words:

biodegradation, halohydrins, P. putida, kinetics, whole cells, cell-free extracts

\section{Introduction}

Chlorinated hydrocarbons are among the most common and widely distributed organic pollutants, and are extremely toxic and persistent in the environment. Epichlorohydrin and its precursors 1,3-dichloro-2-propanol (1,3-DCP), 2,3-dichloro-1-propanol (2,3-DCP), and 3-chloro-1,2-propanediol (3-CPD) are halohydrins that are widely used as reagents in the manufacture of chemicals, solvents, rodent chemosterilants, and precursors for the synthesis of resins, polymers, agrochemicals, and pharmaceuticals ${ }^{1,2}$.

Both 3-CPD and 1,3-DCP can occur as contaminants in drinking-water from water purification plants that use epichlorohydrin-linked cationic polymer-resins or in wastewaters ${ }^{3,4}$. Similar to occupational exposure, environmental exposure to 1,3DCP predominantly occurs from wastes containing epichlorohydrin. Single studies reported that 1,3DCP was present in pulp mill effluents and spent kraft paper bleaching liquors, as well as in a municipal waste landfill leachate ${ }^{3}$.

"Corresponding author: Dimitris Kekos, Tel.: +30 2107723205; Fax: +30 2107723163; e-mail address: kekos@chemeng.ntua.gr
Despite their wide range of applications and occurrence, halohydrins and specifically 1,3-DCP and 3-CPD are considered potential carcinogenic to humans ${ }^{5,6}$. Studies have shown that $3-\mathrm{CPD}$ is carcinogenic to rats in a non-genotoxic way ${ }^{7,8} \cdot 1,3-\mathrm{DCP}$ is also carcinogenic to rodents as well as hepatotoxic $^{9,10}$.

Due to their toxicity, 3-CPD and 1,3-DCP are considered significantly hazardous to human health and the environment. As a result, the competent authorities have established relevant legislation which regulates their use. According to the European Commission, wet strength aids must not contain more than $0.7 \%$ of the chloro-organic substances epichlorohydrin (ECH), 1,3-dichloro-2-propanol (1,3-DCP) and 3-monochloro-1,2-propanediol (MCPD or 3-CPD), calculated as the sum of the three components and related to the dry content of the wet strength agent ${ }^{11}$. Respectively, the current regulation of the US Food and Drug Administration for the use of dimethylamine epichlorohydrin copolymer resin establishes a limit for 1,3-DCP residues in the resin of $1000 \mathrm{ppm}^{12}$.

Microorganisms have evolved a diverse metabolic capacity to transform and degrade halogenated organic compounds ${ }^{13-15}$. The key reaction during microbial degradation of halogenated compounds is 
the actual dehalogenation. During this step, the halogen substituent, which is usually responsible for the toxic and xenobiotic character of the compound, is replaced - either by hydrogen or a hydroxyl group. Halogen removal reduces recalcitrance to biodegradation as well as the risk of forming toxic intermediates during subsequent metabolic steps ${ }^{14}$.

Several microorganisms have been studied for their ability to aerobically degrade halogenated organic compounds. Most of them belong to the bacterial genera of: Arthrobacter, Xanthobacter, Corynebacterium, Rhodococcus and Pseudomonas. The relevant literature has been previously reviewed ${ }^{15,16}$. Much work has been conducted on the identification and characterization of dehalogenating enzymes from the above-mentioned microorganisms, mainly due to the observation that dehalogenation of chiral halohydrins can proceed with high enastioselectivity ${ }^{17,18}$.

The aim of this work was, on the one hand, to identify the metabolic pathway of the degradation of halohydrins by P. putida DSM 437 and, on the other, to investigate the kinetics of degradation of 1,3-DCP and 3-CPD by whole cells and cell-free extract of the same microorganism.

\section{Experimental}

\section{Microorganism}

Bacterial strain Pseudomonas putida DSM 437 was obtained from DSMZ (Deutsche Sammlung von Microorganismen und Zellkulture $\mathrm{GmbH}$ ), Germany. Stock cultures were maintained in glycerol $30 \% \mathrm{w} / \mathrm{w}$ at $-80{ }^{\circ} \mathrm{C}$.

\section{Growth media and conditions}

P. putida DSM 437 was grown in a mineral medium containing $\left(\mathrm{g} \mathrm{L}^{-1}\right): \mathrm{Na}_{2} \mathrm{HPO}_{4}, 2.44 ; \mathrm{KH}_{2} \mathrm{PO}_{4}$, 1.52; $\quad\left(\mathrm{NH}_{4}\right)_{2} \mathrm{SO}_{4}, \quad 0.5 ; \quad \mathrm{MgSO}_{4} \cdot 7 \mathrm{H}_{2} \mathrm{O}, \quad 0.2$; $\mathrm{CaCl}_{2} \cdot 2 \mathrm{H}_{2} \mathrm{O}, 0.05$ and $10 \mathrm{~mL}$ per L of trace elements solution containing $\left(\mathrm{g} \mathrm{L}^{-1}\right)$ : EDTA, 0.5; $\mathrm{FeSO}_{4} \cdot 7 \mathrm{H}_{2} \mathrm{O}, 0.2 ; \mathrm{ZnSO}_{4} \cdot 7 \mathrm{H}_{2} \mathrm{O}, 0.01 ; \mathrm{MnCl}_{2} \cdot 4 \mathrm{H}_{2} \mathrm{O}$, $0.003 ; \mathrm{H}_{3} \mathrm{BO}_{3}, 0,03 ; \mathrm{CoCl}_{2} \cdot 6 \mathrm{H}_{2} \mathrm{O}, 0.02 ; \mathrm{CuCl}_{2}^{2} \cdot 2 \mathrm{H}_{2}^{2} \mathrm{O}$, 0,$001 ; \mathrm{NiCl}_{2} \cdot 6 \mathrm{H}_{2} \mathrm{O}, 0.002 ; \mathrm{Na}_{2} \mathrm{MoO}_{4} \cdot 2 \mathrm{H}_{2} \mathrm{O}, 0.003$. The $\mathrm{pH}$ of the medium was adjusted to 6.9. The medium was sterilized at $120^{\circ} \mathrm{C}$ for $15 \mathrm{~min}$. Following heat sterilization, glucose $\left(2.0 \mathrm{~g} \mathrm{~L}^{-1}\right)$, which was sterilized separately (at $109{ }^{\circ} \mathrm{C}$ for $40 \mathrm{~min}$ ), and 3-CPD (100 $\left.\mathrm{mg} \mathrm{L}^{-1}\right)$ supplemented the mineral medium.

The inoculum was prepared by transferring cell suspension from the stock culture to 2 L Erlenmeyer flasks containing $1 \mathrm{~L}$ of the above medium. The cells were grown at $30{ }^{\circ} \mathrm{C}$ for $24 \mathrm{~h}$ in an orbital shaker $(200 \mathrm{rpm})$, and served as a preculture.
Growth was conducted using the above-mentioned medium in a 20-L stirred bioreactor with 16 L working volume. Bioreactor was inoculated with $10 \%(\mathrm{v} / \mathrm{v})$ of the preculture. Growth was allowed to proceed for $90 \mathrm{~h}$ at $30^{\circ} \mathrm{C}$ in order for the cells to be acclimatized.

\section{Removal of 1,3-DCP and 3-CPD by the acclimatized cells of $P$. putida DSM 437}

Cells were harvested at the late exponential phase, by centrifugation $\left(15 \mathrm{~min}, 10,000 \times \mathrm{g}, 5^{\circ} \mathrm{C}\right)$, washed with $0.02 \mathrm{M}$ Tris/ $\mathrm{HCl} \mathrm{pH} \mathrm{7.0,} \mathrm{and} \mathrm{resus-}$ pended in the same buffer in order to obtain a final biomass concentration of $3.5 \mathrm{~g} \mathrm{DCW} \mathrm{L}^{-1}$. The solubility of 1,3-DCP and 3-CPD in water reaches $100 \mathrm{~g} \mathrm{~L}^{-1}$ at $21{ }^{\circ} \mathrm{C}$. Stock solutions of 1,3-DCP and 3-CPD were prepared by diluting the above-mentioned compounds in deionized water. Different amounts of the appropriate stock solution (1,3-DCP or 3-CPD) were added in 25-mL Erlenmeyer flasks containing the above-mentioned cell suspension, and placed in an orbital shaker $\left(30^{\circ} \mathrm{C}, 200 \mathrm{rpm}\right)$. All reaction mixtures had the same final volume (10 $\mathrm{mL})$. Samples were withdrawn periodically and after centrifugation $(5,000 \times g, 15 \mathrm{~min})$ the supernatant was used for the determination of the remaining 1,3-DCP and 3-CPD as described in the corresponding paragraph. Additionally, the liberation of chloride ions was determined as described elsewhere ${ }^{19}$ confirming that the removal of 1,3-DCP and 3-CPD is the result of a dehalogenation taking place. All experiments were conducted in duplicate.

In order to reject the hypothesis that the observed decrease in the concentrations of 1,3-DCP and 3-CPD is due to adsorption of the compounds to biomass, two different approaches were applied: (a) the biomass remaining after centrifugation of the samples was extracted, applying the method of Mueller and Fischer ${ }^{20}$ and (b) the cells were deactivated by boiling and after addition of the appropriate substrate were placed in the orbital shaker for incubation. Samples were withdrawn periodically and after centrifugation $(5,000 \times \mathrm{g}, 15 \mathrm{~min})$ the supernatant was used for the determination of the remaining 1,3-DCP and 3-CPD as described below. All experiments were conducted in duplicate.

\section{Removal of 1,3-DCP and 3-CPD by the cell-free extract}

Cells were harvested from cultures at the late exponential phase by centrifugation (15 $\mathrm{min}, 10,000$ $\times g, 5^{\circ} \mathrm{C}$ ), washed once with $0.02 \mathrm{M}$ Tris $/ \mathrm{HCl} \mathrm{pH}$ 7.0, and suspended in the same buffer that contained also $2 \mathrm{mM}$ PMSF (Phenylmethanesulfonyl fluoride) for the inhibition of proteolysis. The ratio cell pel- 
let:buffer was 1:1 w/w. The cell suspension was kept at $-20{ }^{\circ} \mathrm{C}$. Following ultrasonic disruption of the ice-cold cells, a crude extract $(6 \mathrm{~g}$ total protein $\mathrm{L}^{-1}$ ) was obtained. Different amounts of the appropriate stock solution (1,3-DCP, 3-CPD) were added in $25-\mathrm{mL}$ Erlenmeyer flasks containing the above-mentioned crude extract and placed in an orbital shaker $\left(30^{\circ} \mathrm{C}, 200 \mathrm{rpm}\right)$. The final volume of the reaction was $3 \mathrm{~mL}$. Samples were withdrawn periodically and after centrifugation $(5,000 \times g, 15$ $\mathrm{min}$ ) the supernatant was used for the identification of intermediate metabolites by GC-MS and the determination of the remaining 1,3-DCP and 3-CPD. Blank samples, containing boiled crude extract and 1,3-DCP or 3-CPD, were used.

\section{Analytical methods}

\section{Biomass estimation}

Cell growth was monitored by measuring the optical density of culture samples using a spectrophotometer (Hitachi UV 1100, Japan) at $600 \mathrm{~nm}$. The biomass concentration was calculated from optical density measurements using a standard curve prepared with $P$. putida cells grown on glucose and expressed as dry weight $\left(\mathrm{g} \mathrm{DCW} \mathrm{L}^{-1}\right)$.

\section{Protein estimation}

Protein concentration in cell-free extracts was determined according to the Bradford method ${ }^{21}$.

\section{1,3-DCP and 3-CPD determination}

Prior to determination, 1,3-DCP and 3-CPD were extracted three times from the samples with ethyl acetate ${ }^{20}$. 1,3-DCP and 3-CPD were determined with a Shimadzu gas chromatograph GC$17 \mathrm{~A}$ as described elsewhere ${ }^{22}$.

\section{GC-MS identification of metabolites}

Selected samples from the experiments with the cell-free extract were used for the identification of biodegradation metabolites. In some cases, derivatization with N,O-Bis-(trimethylsilyl) trifluoroacetamide (BSTFA) followed ethyl acetate extraction. Derivatization was applied in order to improve the analysis. For the derivatization, $50 \mu \mathrm{L}$ BSTFA were added to $500 \mu \mathrm{L}$ sample followed by a $30 \mathrm{~min}$ incubation at $60{ }^{\circ} \mathrm{C}$.

GC separation was performed using a Varian 450 GC coupled to a mass spectrometer MS IT 220 operated in the selected ion trap mode. The capillary column used was a FactorFour ${ }^{\mathrm{TM}}$ VF-5ms (Agilent), $30 \mathrm{~m}$ in length, $0.25 \mathrm{~mm}$ inner diameter and $0.25 \mu \mathrm{m}$ film thickness. Helium (99.999\%) was used as the carrier gas at a constant flow rate of 1.0
$\mathrm{mL} \min ^{-1}$. For the analysis of 3-CPD and 1,3-DCP, the $\mathrm{GC}$ oven was programmed as follows: $40{ }^{\circ} \mathrm{C}$ (kept for $2 \mathrm{~min}$ ), increased at a rate of $2{ }^{\circ} \mathrm{C} \mathrm{min}^{-1}$ to $80{ }^{\circ} \mathrm{C}$ (kept for $2 \mathrm{~min}$ ), finally from 80 to $280{ }^{\circ} \mathrm{C}$ at a rate of $30{ }^{\circ} \mathrm{C} \mathrm{min}^{-1}$ (kept for $2 \mathrm{~min}$ ). For the analysis of glycerol, the temperature program was as follows: $115^{\circ} \mathrm{C}$ (held for $1 \mathrm{~min}$ ), increased at a rate of $5{ }^{\circ} \mathrm{C} \mathrm{min}{ }^{-1}$ to $130{ }^{\circ} \mathrm{C}$, finally from 130 to $250{ }^{\circ} \mathrm{C}$ at a rate of $30{ }^{\circ} \mathrm{C} \mathrm{min}-1$ (held for $2 \mathrm{~min}$ ). The mass spectrometer was operated in electron impact (EI) mode, $70 \mathrm{eV}$ of ion energy, with a $10 \mathrm{~min}$ solvent delay. The temperatures of the sampler, the transfer line, and the mass analyzer were set at 280, 200, and $170{ }^{\circ} \mathrm{C}$, respectively. Standards and sample extracts were injected in the splitless mode (splitless time $1.5 \mathrm{~min}$ ), with the injector port at $280{ }^{\circ} \mathrm{C}$.

\section{Degradation kinetics}

The biodegradation rates for the two compounds under examination were determined using the initial linear part of the degradation curves. The maximum biodegradation activity $\left(v_{\max }\right)$ and the saturation constant $\left(K_{\mathrm{m}}\right)$ were determined by assuming Michaelis-Menten kinetics.

\section{Results and discussion}

\section{Removal of 1,3-DCP and 3-CPD by acclimatized cells of $P$. putida DSM 437}

Preliminary experiments showed that the direct degradation of both halohydrins by liquid cultures of $P$. putida DSM 437 was limited (data not shown). In this case, 1,3-DCP or 3-CPD were used as sole carbon sources and the mineral medium was the same as described in the Experimental. The percent degradation for 3-CPD (initial concentration 4.52 $\mathrm{mM}$, corresponding to $500 \mathrm{mg} \mathrm{L}^{-1}$ ) did not exceed $30 \%$ after $124 \mathrm{~h}$ of incubation. Respectively, no degradation was observed for 1,3-DCP in concentrations higher than $0.90 \mathrm{mM}$ (corresponding to 100 $\mathrm{mg} \mathrm{L}^{-1}$ ) verifying the toxic character of the compound. The limited performance of $P$. putida DSM 437 cultures in the biodegradation of both halohydrins examined drove us to examine the use of concentrated and acclimatized to 3-CPD and 1,3-DCP biomass (whole cells), in order to study the degradation kinetics.

During acclimatization, glucose was added as carbon and energy source in order to enhance cell growth, while the chloropropanols were supplemented in order to induce the enzymes implicated in their degradation. Acclimatization was selected as a way to increase the level of degradation, especially for 1,3-DCP, and to decrease the lag phase 
Table 1 -Kinetic parameters of 1,3-DCP and 3-CPD degradation by whole cells of P. putida DSM 437

\begin{tabular}{c|c|c}
\hline Halohydrin & $\begin{array}{c}v_{\max } \\
\left(\mathrm{mmol} \mathrm{mg}^{-1} \mathrm{DCW} \mathrm{h}^{-1}\right)\end{array}$ & $\begin{array}{c}K_{\mathrm{m}} \\
(\mathrm{mM})\end{array}$ \\
\hline 1,3-DCP & $2.78 \cdot 10^{-6}$ & 4.03 \\
3-CPD & $1.28 \cdot 10^{-5}$ & 3.45 \\
\hline
\end{tabular}

observed when degradation was studied in bacterial cultures (data not shown). As it has been previously reported, the addition of conventional carbon sources, such as glucose, yeast extract, and sodium glutamate is considered a promising approach to increase cell tolerance towards substrate inhibition ${ }^{23}$.

Acclimatized cells were harvested at late exponential phase as described in Materials and methods, and used to investigate degradation for both halohydrins at concentrations ranging from 0.39 $3.68 \mathrm{mM}$ (corresponding to $50-500 \mathrm{mg} \mathrm{L}^{-1}$ ) for 1,3-DCP and $0.45-4.52 \mathrm{mM}$ (corresponding to $50-500 \mathrm{mg} \mathrm{L}^{-1}$ ) for 3-CPD. When acclimatized biomass was used, the removal of 1,3-DCP was observed in every concentration tested, in contrast to the direct removal mentioned above. The degradation profiles of 1,3-DCP and 3-CPD at different initial concentrations by the concentrated acclimatized cells of $P$. putida DSM 437 are presented in Figure $1 \mathrm{a}$ and $1 \mathrm{~b}$, respectively. 1,3-DCP removal was found in the range of $25 \%$ for all concentrations tested. On the other hand, 3-CPD removal ranged from $47 \%$ to $79 \%$, depending on the initial 3-CPD concentration. 1,3-DCP and 3-CPD disappearance rates increased with 1,3-DCP and 3-CPD concentrations, respectively. The maximum biodegradation rate $\left(v_{\text {max }}\right)$ and the saturation constant $\left(K_{\mathrm{m}}\right)$ were estimated from the Lineweaver-Burk plot (Figure 1a and $1 \mathrm{~b}$ insets). The results are presented in Table 1 . The affinity towards both halohydrins was practically the same as judged by the calculated $K_{\mathrm{m}}$ values. However, the maximum biodegradation rate of 3-CPD was determined more than 4 times higher than that of 1,3-DCP (Table 1).

Biodegradation rates of 1,3-DCP in the present study ranged from 0.001 to $0.006 \mathrm{mmol} \mathrm{L}^{-1} \mathrm{~h}^{-1}$ depending on initial 1,3-DCP concentration. Fauzi et al. ${ }^{19}$ reported the biodehalogenation of low concentrations of 1,3-DCP by Agrobacterium sp. strain A1. The process showed a similar rate of 0.0038 mmol L ${ }^{-1} \mathrm{~h}^{-1}$ at concentrations of 1,3-DCP from 0.0077 to $0.077 \mathrm{mM}$. On the other hand, higher degradation rates were reported by Bastos et al. ${ }^{24}$ using microbial consortia for the degradation of 1,3-DCP $\left(0.024 \mathrm{mmol} \mathrm{L}^{-1} \mathrm{~h}^{-1}\right)$, and Yonetani et al..$^{25}$ using Arthrobacter $s p$. strain PY1 (0.185 mmol L $\mathrm{L}^{-1}$ ).
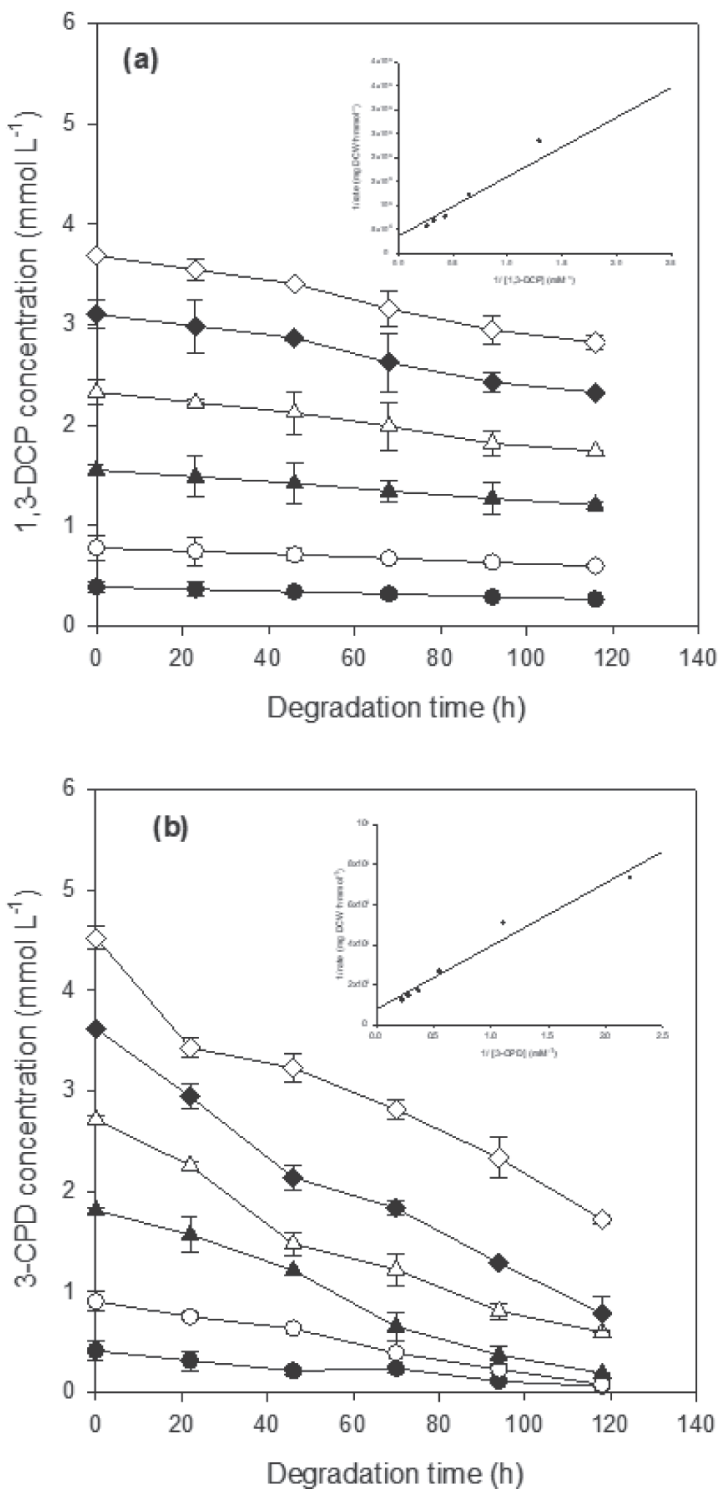

Fig. 1 - (a) 1,3-DCP biodegradation by whole cells of $P$. putida DSM 437. 1,3-DCP was added to yield initial concentrations of ( $0.39 \mathrm{mM},(\mathrm{O}) 0.78 \mathrm{mM}$, ( $\mathbf{\Delta}) 1.55 \mathrm{mM},(\triangle)$ $2.33 \mathrm{mM}$, $(\diamond) 3.10 \mathrm{mM}$ and $(\diamond) 3.68 \mathrm{mM}$ and (b) 3-CPD biodegradation by whole cells of P. putida DSM 437. 3-CPD was added to yield initial concentrations of (О) $0.45 \mathrm{mM}$, (O) 0.90

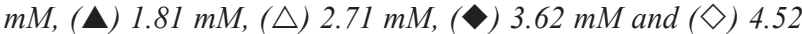
$\mathrm{mM} . K_{m}$ and $v_{\max }$ values were estimated from the Lineweaver-Burk plot (insets).

\section{Degradation of 3-CPD and 1,3-DCP by cell-free extract of $P$. putida DSM 437}

The degradation of 3-CPD and 1,3-DCP was further studied using cell-free extracts in order to elucidate the metabolic pathway and estimate the kinetic constants of this process. GC-MS analysis was performed in cell-free extracts supplemented with 1,3-DCP (sampling time: $0 \mathrm{~h}$ and $24 \mathrm{~h}$ incubation). Specifically, after $24 \mathrm{~h}$ of incubation, apart from the remaining 1,3-DCP, 3-CPD and glycerol were also detected. Initially, the quality of the anal- 


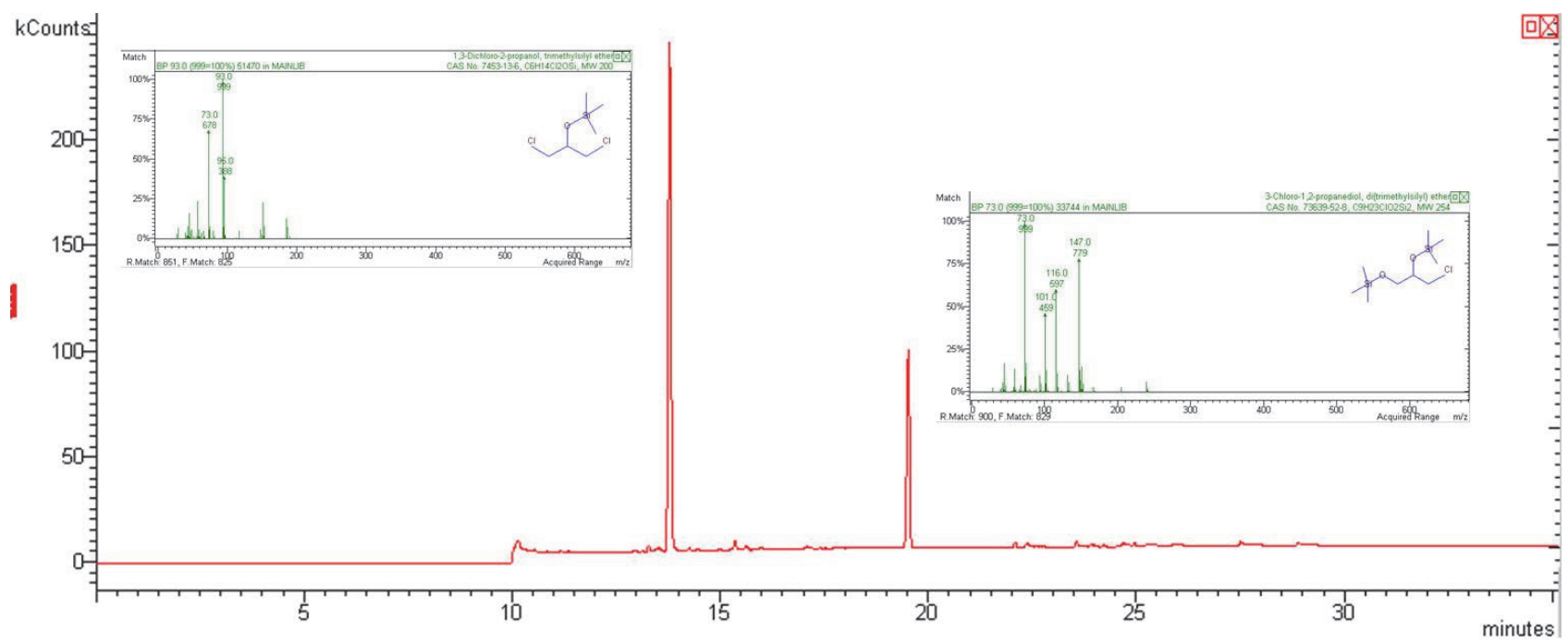

Fig. 2 - Chromatogram and MS spectra identifying the derivatives of 1,3-DCP and 3-CPD after 24 hours of incubation of cell-free extract of P. putida DSM 437 supplemented with 1,3-DCP

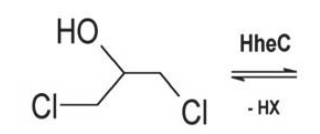

1,3-dichloro-2-propanol
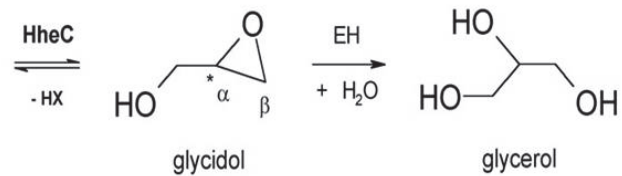

F ig. 3 - Metabolic pathway for the degradation of 1,3-DCP $6,15,26$

ysis was poor, and the separation and identification of 1,3-DCP and 3-CPD was not clear (data not shown). However, the presence of 3-CPD was confirmed when derivatization with BSTFA was employed, following the extraction with ethyl acetate. Derivatization definitively improved the quality of the analysis. In this case, retention times for the derivatives of 1,3-DCP and 3-CPD were 13.802 and 19.474 , respectively (Figure 2). As far as glycerol is concerned, the samples were analyzed without further treatment (extraction with ethyl acetate and derivatization) but with a different temperature gradient as described in Materials and methods. The retention time of glycerol was $10.303 \mathrm{~min}$.

The degradation of 1,3-DCP is considered to follow the proposed metabolic pathway (Figure $3)^{6,15,26}$. The first reaction of the pathway is supposed to be the dehalogenation of 1,3-DCP to epichlorohydrin by a haloalcohol dehalogenase (also also known as haloalcohol dehalogenases or halohydrin hydrogen-halide lyase, HDDH). Haloalcohol dehalogenases catalyze the intramolecular displacement of a halogen by the vicinal hydroxyl group in 1,3-DCP, yielding its corresponding epoxide, a halide ion, and a proton without the need of cofactors $^{26-27}$. In concert with a well characterized epoxide hydrolase, the haloalcohol dehalogenase constitutes an efficient degradation pathway of 1,3DCP and epichlorohydrin into non-toxic metabolites. 3-CPD, which is considered the next intermediate of the pathway, is transformed to glycidol by haloalcohol dehalogenase, whereas glycerol is the final product ${ }^{15,28}$. Haloalcohol dehalogenases have broad substrate specificity and enantioselectivity towards aliphatic as well as aromatic vicinal haloalcohols $^{27}$.

Cell-free extract of acclimatized cells of $P$. putida DSM 437 was used for 1,3-DCP and 3-CPD degradation studies as described in Materials and methods. 1,3-DCP and 3-CPD disappearance rates increased with 1,3-DCP and 3-CPD concentrations, respectively (Figure 4$)$. The maximum biodegradation rate $\left(v_{\max }\right)$ and the saturation constant $\left(K_{\mathrm{m}}\right)$ were estimated from the Lineweaver-Burk plots (Figure 4). The results are presented in Table 2. As in the case of whole cells, the maximum biodegradation rate of 3-CPD was higher (2.5-fold) than that of

Table 2 - Kinetic parameters of 1,3-DCP and 3-CPD degradation by cell-free extract of P. putida DSM 437

\begin{tabular}{c|c|c}
\hline Halohydrin & $\begin{array}{c}v_{\max } \\
\left(\mathrm{mmol} \mathrm{mg}^{-1} \mathrm{protein}^{-1}\right)\end{array}$ & $\begin{array}{c}K_{\mathrm{m}} \\
(\mathrm{mM})\end{array}$ \\
\hline 1,3-DCP & $9.61 \cdot 10^{-6}$ & 8.00 \\
3-CPD & $2.42 .10^{-5}$ & 9.07 \\
\hline
\end{tabular}



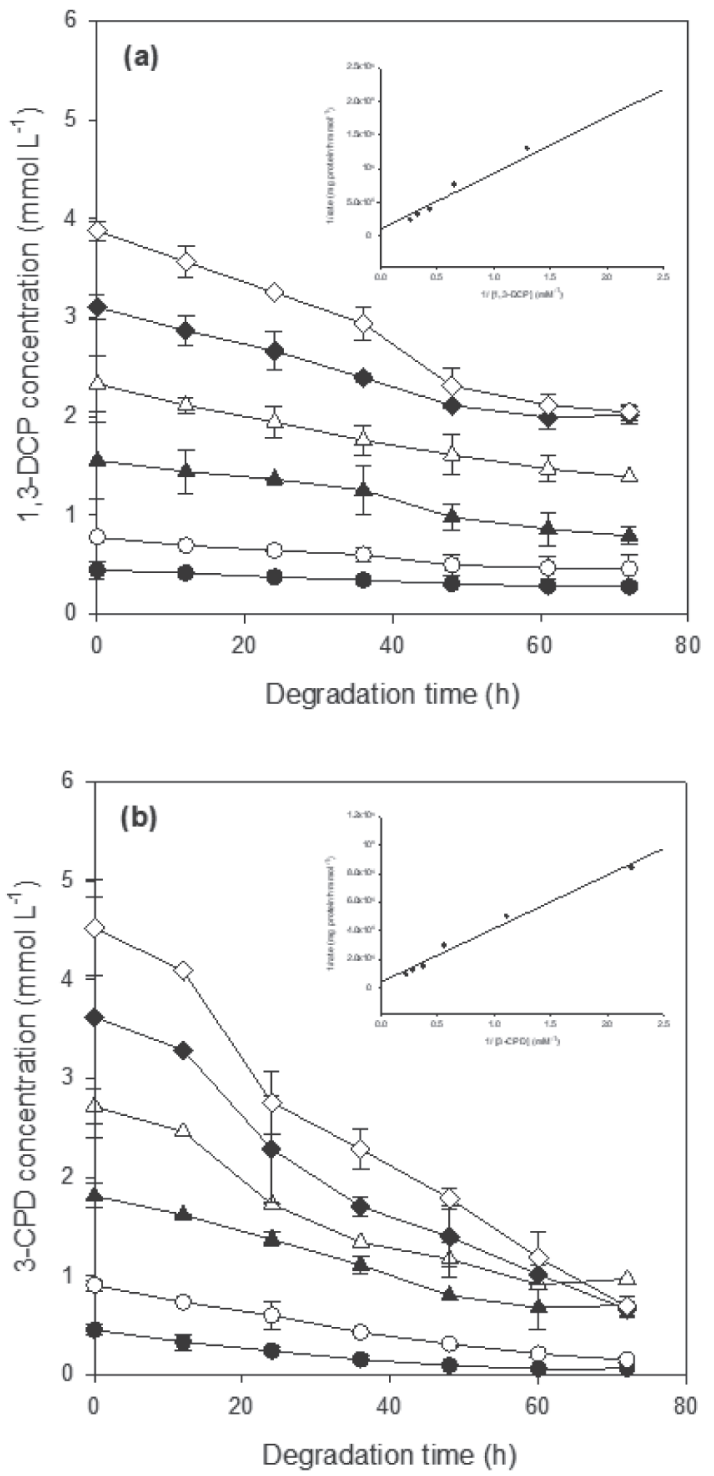

Fig. 4-3-CPD and 1,3-DCP biodegradation kinetics by cell-free extract of P. putida DSM 437. (a) 1,3-DCP was added to yield initial concentrations of (O) $0.39 \mathrm{mM}$, (O) $0.78 \mathrm{mM}$,

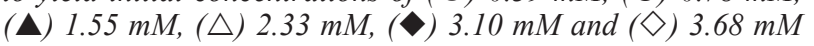
and (b) 3-CPD was added to give initial concentrations of (O) $0.45 \mathrm{mM}$, (О) $0.90 \mathrm{mM},(\mathbf{\Delta}) 1.81 \mathrm{mM},(\triangle) 2.71 \mathrm{mM}$, (४) 3.62 $\mathrm{mM}$ and $(\diamond) 4.52 \mathrm{mM} . K_{m}$ and $v_{\max }$ values were estimated from the Lineweaver-Burk plot (insets).

1,3-DCP, while the cell-free extract exhibited slightly higher affinity towards 1,3-DCP (Table 2). It should be noted that the removal of 1,3-DCP by the cell-free extract was found higher than $50 \%$ in all concentrations tested, while 3-CPD removal ranged from $60 \%$ to $80 \%$ depending on the initial 3-CPD concentration.

Furthermore, the ability of cell-free extract to degrade ECH was examined (Figure 5). ECH disappearance rates increased with ECH concentration. Removal of approximately 66 and $85 \%$ was observed when cell-free extract was supplemented

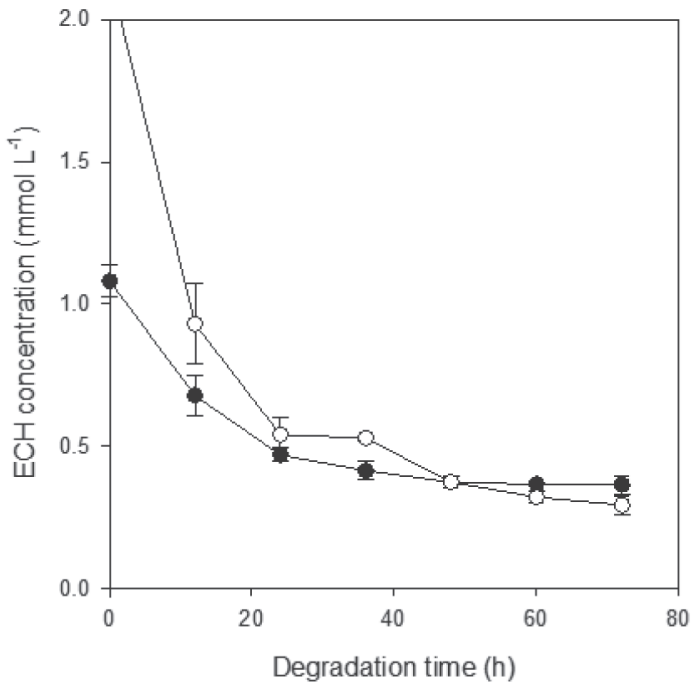

Fig. 5 - ECH biodegradation kinetics by cell-free extract of P. putida DSM 437. ECH was added to give initial concentrations of (O) $1.08 \mathrm{mM}$ and (O) $2.16 \mathrm{mM}$.

with 1.08 and $2.16 \mathrm{mM}$ of $\mathrm{ECH}$, respectively. Disappearance of $\mathrm{ECH}$ proceeded in a much faster rate compared to that of 1,3-DCP, providing an explanation for the fact that no ECH was detected during 1,3-DCP degradation.

Rates of 3-CPD degradation, at a fixed concentration of $0.90 \mathrm{mM}$, were determined in the presence of different concentrations of two intermediates of the dehalogenation pathway, namely ECH and glycidol (Figure 6a and 6b, respectively). ECH and glycidol were observed to inhibit 3-CPD degradation in a concentration-dependent manner (Figure 6). A decrease of about $69.1 \%$ in the rate of 3-CPD degradation was observed when $4.05 \mathrm{mM}$ of glycidol were added to the reaction mixture. On the other hand, the rate of 3-CPD degradation radically decreased upon addition of $3.23 \mathrm{mM} \mathrm{ECH}$. The decrease reached $91 \%$ (Figure 6b). This indicates that $\mathrm{ECH}$ is by far the most potent inhibitor of 3-CPD degradation by the cell-free extract of $P$. putida DSM 437. Inhibition of the enzyme (a halohydrin dehalogenase) catalyzing the transformation of 1,3DCP to ECH has been confirmed by previous studies $^{29-30} . \mathrm{IC}_{50}$ is the concentration of an inhibitor required to reduce the rate of an enzymatic reaction by $50 \%$. Calculated values of $\mathrm{IC}_{50}$ for 3 -CPD degradation in the presence of $\mathrm{ECH}$ and glycidol were found 0.57 and $2.01 \mathrm{mM}$, respectively. The insets in Figure 6 depict the Dixon plot of inhibitor concentration versus 3-CPD degradation rate. Though more than one set of data are required to determine the mechanism of inhibition, the data provided allow us to estimate the dissociation constant $K_{\mathrm{i}}$, to be less than $0.32 \mathrm{mM}$ and $1.81 \mathrm{mM}$ for $\mathrm{ECH}$ and glycidol, respectively. 

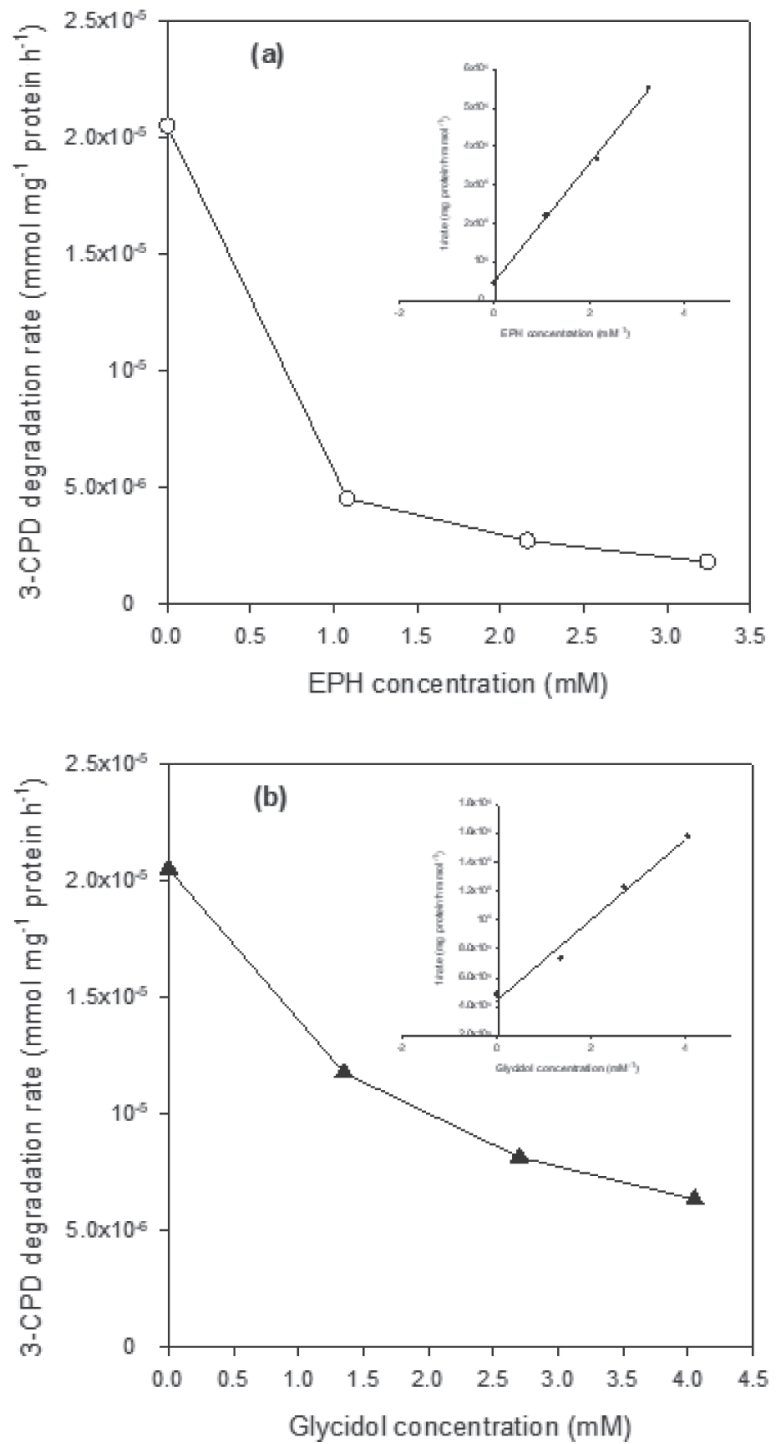

Fig. 6 - Inhibition of 3-CDP by degradation rate by (a) epichlorohydrin and (b) glycidol. The insets depicts the results plotted as a Dixon plot, inverse rate versus inhibitor concentration.

\section{Conclusions}

Biodegradation of 1,3-DCP and 3-CPD by $P$. putida DSM 437 batch cultures was limited. The use of concentrated acclimatized biomass improved the degradation levels. Both 1,3-DCP and 3-CPD disappearance rates exhibited first-order kinetics, and increased with 1,3-DCP and 3-CPD concentrations. The use of cell-free extracts allowed us to investigate the corresponding metabolic pathway and mainly improved the removal of 3-CPD at the higher concentrations tested. The sequence of the reactions proposed is confirmed by literature. When other intermediates, namely epichlorohydrin and glycidol, were added to the cell-free extract to examine their potential inhibitory influence, it was proved that epichlorohydrin is a potent inhibitor of 3-CPD biodegradation.

\section{ACKNOWLEDGEMENTS}

Aikaterini Konti is grateful to the State Scholarships' Foundation of Greece for a PhD grant.

The authors would like to thank Dr. Theopisti Lymperopoulou and Ms Kalliopi Balta for their contribution to the GC-MS analysis.

\section{References}

1. Kasai, N., Tsujimura, K., Unoura, K., Suzuki, T., Degradation of 2,3-dichloro-1-propanol by a Pseudomonas sp., Agr. Biol. Chem. Tokyo 54(12) (1990) 3185.

doi: https://doi.org/10.1080/00021369.1990.10870490

2. Effendi, A. J., Greenaway, S. D., Dancer, B. N., Isolation and characterization of 2,3-dichloro-1-propanol-degrading rhizobia, Appl. Environ. Microb. 66(7) (2000) 2882. doi: https://doi.org/10.1128/AEM.66.7.2882-2887.2000

3. URL: https://ntp.niehs.nih.gov/ntp/htdocs/chem_background/exsumpdf/dichloropropanol 508.pdf (20/04/2016).

4. Nienow, A. M., Poyer, I. C., Hua, I., Jafvert, C. T., Hydrolysis and $\mathrm{H}_{2} \mathrm{O}_{2}$-assisted UV photolysis of 3-chloro-1,2-propanediol, Chemosphere 75(8) (2009) 1015.

doi: https://doi.org/10.1016/j.chemosphere.2009.01.053

5. URL: https://monographs.iarc.fr/ENG/Monographs/vol101/ mono101-010.pdf (20/04/2016)

6. URL: https://monographs.iarc.fr/ENG/Monographs/vol101/ mono101-011.pdf (20/04/2016)

7. Robjohns, S., Marshall, R., Fellows, M., Kowalczyk, G., In vivo genotoxicity studies with 3-monochloropropan-1,2-diol, Mutagenesis 18(5) (2003) 401. doi: https://doi.org/10.1093/mutage/geg017

8. El Ramy, R., Ould Elhkim, M., Lezmi S., Poul, J. M., Evaluation of the genotoxic potential of 3-monochloropropane-1,2-diol (3-MCPD) and its metabolites, glycidol and $\beta$-chlorolactic acid, using the single cell gel/comet assay, Food Chem. Toxicol. 45(1) (2007) 41. doi: https://doi.org/10.1016/j.fct.2006.07.014

9. Hammond, A. H., Fry, J. R., Effect of cyanamide on toxicity and glutathione depletion in rat hepatocyte cultures: Differences between two dichloropropanol isomers, Chem-Biol Interact. 122(2) (1999) 107. doi: https://doi.org/10.1016/S0009-2797(99)00118-0

10. Williams, G., Leblanc, J.-C., Setzer, R. W., Application of the margin of exposure (MoE) approach to substances in food that are genotoxic and carcinogenic: Example: (CAS No. 96-23-1) 1,3-Dichloro-2-propanol (DCP), Food Chem. Toxicol. 48 Supplement 1 (2010) S57. doi: https://doi.org/10.1016/j.fct.2009.10.038

11. 2009/568/EC Commission Decision establishing the ecological criteria for the award of the Community Eco-label for tissue paper. Off J Europ Comm. L.197/87

12. URL: http://www.accessdata.fda.gov/scripts/cdrh/cfdocs/cfcfr/ CFRSearch.cfm? fr=173.60 (20/04/2016)

13. Fetzner, S., Bacterial dehalogenation, Appl. Microbiol. Biot. 50(6) (1998) 633. doi: https://doi.org/10.1007/s002530051346

14. Janssen, D. B., Oppentocht, J. E., Poelarends, G. J., Microbial dehalogenation, Curr. Opin. Biotech. 12(3) (2001) 254. doi: https://doi.org/10.1016/S0958-1669(00)00208-1

15. Fetzner, S., Aerobic Degradation of Halogenated Aliphatics, in Handbook of Hydrocarbon and Lipid Microbiology, Timmis, K. N. (Ed.), Springer Berlin Heidelberg (2010) pp. 865-885.

doi: https://doi.org/10.1007/978-3-540-77587-4_62 
16. Bhatt, P., Kumar, M. S., Mudliar, S., Chakrabarti, T., Biodegradation of chlorinated compounds - A review, Crit. Rev. Env. Sci. Tech. 37(2) (2007) 165. doi: https://doi.org/10.1080/10643380600776130

17. Nakamura, T., Nagasawa, T., Yu, F., Watanabe, I., Yamada, $H$., Characterization of a novel enantioselective halohydrin hydrogen-halide-lyase, Appl. Env. Microb. 60(4) (1994) 1297.

18. Assis, H. M. S., Sallis, P. J., Bull, A. T., Hardman, D. J., Biochemical characterization of a haloalcohol dehalogenase from Arthrobacter erithii H10a, Enzyme Microb. Tech. 22(7) (1998) 568. doi: https://doi.org/10.1016/S0141-0229(97)00254-8

19. Fauzi, A. M., Hardman, D. J., Bull, A. T., Biodehalogenation of low concentrations of 1,3-dichloropropanol by mono- and mixed cultures of bacteria, Appl. Microbiol. Biotech. 46(5) (1996) 660. doi: https://doi.org/10.1007/s002530050877

20. Mueller, T., Fischer S. A., Determination of organic chloride impurities in polyaminoamide-epichlorohydrin resins by gas chromatography, TAPPI J. 75(4) (1992) 159.

21. Bradford, M. M., A rapid and sensitive method for the quantitation of microgram quantities of protein utilizing the principle of protein-dye binding, Anal. Biochem. 72(1-2) (1976) 248. doi: https://doi.org/10.1016/0003-2697(76)90527-3

22. Mamma, D., Papadopoulou, E., Petroutsos, D., Christakopoulos, P., Kekos, D., Removal of 1,3-dichloro-2-propanol and 3-chloro1,2-propanediol by the whole cell system of Pseudomonas putida DSM 437, J. Environ. Sci. Heal. A 41 (2006) 303 doi: https://doi.org/10.1080/10934520500423154

23. Wang, S. J., Loh, K. C., Growth kinetics of Pseudomonas putida in cometabolism of phenol and 4-chlorophenol in the presence of a conventional carbon source, Biotechnol. Bioeng. 68(4) (2000) 437.

doi: https://doi.org/10.1002/(SICI)1097-0290(20000520)68: 4<437::AID-BIT9>3.0.CO; 2-G
24. Bastos, F., Bessa, J. E., Pacheco, C. C., De Marco, P., Castro, P. M. L., Silva, M., Jorge, R. F., Enrichment of microbial cultures able to degrade 1,3-dichloro-2-propanol: a comparison between batch and continuous methods, Biodegradation 13 (2002) 211 doi: https://doi.org/10.1023/A:1020834603785

25. Yonetani, R., Ikatsu, H., Miyake-Nakayama, C., Fujiwara, E., Maehara, Y., Miyoshi, S., Matsuoka, H., Shinoda, S., Isolation and characterization of a 1,3-dichloro-2-propanol-degrading bacterium, J. Health Sci. 50 (2004) 605. doi: https://doi.org/10.1248/jhs.50.605

26. De Jong, R. M., Tiesinga, J. J. W., Rozeboom, H. J., Kalk, K. H., Tang, L., Janssen, D. B., Dijkstra, B. W., Structure and mechanism of a bacterial haloalcohol dehalogenase: A new variation of the short-chain dehydrogenase/reductase fold without an $\mathrm{NAD}(\mathrm{P}) \mathrm{H}$ binding site, EMBO Journal 22(19) (2003) 4933. doi: https://doi.org/10.1093/emboj/cdg479

27. You, Z. Y., Liu, Z. Q., Zheng, Y. G., Properties and biotechnological applications of halohydrin dehalogenases: Current state and future perspectives, Appl. Microbiol. Biotech. 97(1) (2013) 9. doi: https://doi.org/10.1007/s00253-012-4523-0

28. Van Den Wijngaard, A. J., Janssen, D. B., Witholt, B., Degradation of epichlorohydrin and halohydrins by bacterial cultures isolated from freshwater sediment, Journal of Gen. Microbiol. 135(8) (1989) 2199. doi: https://doi.org/10.1099/00221287-135-8-2199

29. Jin, H. X., Hu, Z. C., Liu, Z. Q., Zheng, Y. G., Nitrite-mediated synthesis of chiral epichlorohydrin using halohydrin dehalogenase from Agrobacterium radiobacter AD1, Biotech. Appl. Biochem. 59(3) (2012) 170. doi: https://doi.org/10.1002/bab.1004

30. Zou, S. P., Du, E. H., Hu, Z. C., Zheng, Y. G., Enhanced biotransformation of 1,3-dichloro-2-propanol to epichlorohydrin via resin-based in situ product removal process, Biotechnol. Lett. 35 (2013) 937. doi: https://doi.org/10.1007/s10529-013-1165-y 